\title{
SIMULATION OF FERRY QUE MANAGEMENT SYSTEM IN CROATIA
}

\author{
Dino Županović, Ana Pejdo, Lena Mirošević
}

Preliminary communication

The main purpose of this paper was to analyse and describe vehicular queues created because of waiting time needed for vehicles to be boarded on ferries during the main tourist (summer) season in the Republic of Croatia. Since optimization of such large and high scale offer and demand system, including both road traffic and ferry infrastructure, could not have been tested in real time conditions, the main idea was to conduct analysis using computer based simulation model. Additionally, optimization of the overall system inelasticity has been conducted based on implementation of the Ferry Que Management System (FQMS). Simulation output analysis indicated the FQMS implementation to be feasible for most of analysed ferry lines but at the same time, it clearly indicated that each ferry line requires individual approach for an optimal solution to be found. The simulation output analysis also provided a clear indication of optimization limitations defined by input values.

Keywords: ferry; management; que; road; simulation; system; traffic

\section{Simulacija primjene sustava upravljanja redovima čekanja u trajektnim lukama u Hrvatskoj}

Problem istraživanja obrađen u ovom radu predstavlja pojava redova čekanja koji nastaju u trajektnim lukama prilikom ukrcaja vozila na trajekte za vrijeme glavne turističke sezone u Republici Hrvatskoj. S obzirom da optimizacija velikog i složenog promatranog sustava koji uključuje ponudu $i$ potražnju za cestovnom i trajektnom infrastrukturom nije mogla bili izvedena u stvarnim uvjetima, osnovna ideja iznesena u članku predstavlja provođenje optimizacije pomoću računalnih simulacijskih modela koji u sebi sadrže ugrađenu logiku upravljanja redovima čekanja u trajektnim lukama (Ferry Que Management System - FQMS). Rezultati dobiveni izvođenjem simulacija dokazali su primjenjivost FQMS sustava na većini trajektnih linija, ali su istovremeno pokazali nužnost pojedinačne analize trajektnih linija u cilju pronalaženja optimalnog rješenja. Dobiveni rezultati također jasno ukazuju na optimizacijska ograničenja uvjetovana ograničenjima stvarnih elemenata promatranog sustava

Ključne riječi: cestovni; promet; redovi čekanja; simulacija; sustav; trajekt; upravljanje

\section{Introduction}

Analysis and que management systems generally represent a well-known scientific field but intensive technological, technical and cultural development of human society undoubtedly led to the development of different types of queues each requiring diverse analysis approach. Que management systems have been successfully applied on a wide area starting from "in facilities" que management systems used in banks, supermarkets, hospitals and other places providing various services to people. They have also been successfully applied for regulation of vehicular traffic flows on both microscopic (intersection) and mesoscopic (intersection grid) scale like the best-known and widely used Sydney Coordinated Adaptive Traffic System

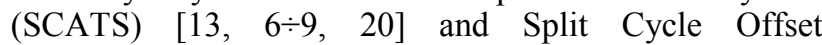
Optimization Technique (SCOOT) [6, 7, 9, 15, 20]. Vehicular traffic flow characteristics have also been proposed and studied on microscopic $[16 \div 18,20]$ and macroscopic scale $[2,19]$ and more interestingly with the same postulates still applicable after more than 80 years of their first introduction [19]. Therefore, someone could conclude falsely that there are no more problems left to be analysed regarding que management systems, nevertheless there is no research dealing with que management on all three levels, micro, mezzo and macroscopic all together. Hence, the purpose of this paper is to examine que management phenomenon on all three levels at the same time, forming a specific and unique scientific approach in the field of que management analyses.

The main purpose was to analyse and describe vehicular queues created because of waiting time needed for vehicles to be boarded on ferries during the main tourist (summer) season in the Republic of Croatia.
Analysed phenomena are characterised by very high demand for ferry transportation services during summer and high seasonality; queues do not appear during the rest of the year. Due to large operational costs and a high price of new/used ferries, an optimal solution should be achieved by implementation of ferry system load optimization based on currently available ferry capacities. Therefore, current situation regarding ferry capacities and accordingly offer and demand in maritime traffic can be described as inelastic as they cannot be increased/decreased instantly to meet volatile (most commonly increasing) demand.

Since optimization of such large and high scale offer and demand system including both road traffic and ferry infrastructure could not have been tested in real time conditions main idea was to conduct analysis using computer based simulation model. Such approach provided not only the possibility to analyse a large-scale model with several static and dynamic components and entities, it also provided much needed flexibility to test various optimization scenarios. The basic idea for optimization of the analysed system is based on the implementation of Ferry Que Management System (FQMS) and reduction of overall analysed system inelasticity - improving road traffic flow harmonization using touristic attractions, specifically Croatian national parks. Results and efficiency of FQMS implementation (road traffic flow harmonization) were measured using ferry port queue waiting times values in minutes.

Due to its complexity, a detailed description of FQMS and its principles are not presented in this paper; only the final application outcomes were taken as relevant [3]. In order to achieve harmonized (planned) vehicle arrival i.e. macroscopic traffic flow harmonization into ferry ports followed by instant vehicle boarding aboard ferry optimization concept encompassed in FQMS relies 
on the principle of providing certain group of users entities - vehicles privilege for priority ferry boardinggrant such vehicles right for immediate ferry boarding upon their arrival into ferry port, therefore minimizing vehicle(s) waiting time as one of the most important factors on passengers' satisfaction [10].

\section{Scope of the work}

For such a system to become applicable, road traffic flow harmonization centres in form of national parks were designed into system models. National parks were selected based on three criteria: their location or distance in relation to border crossings and ferry ports, their capacity/ability to accept a greater number of vehicles, and because they present adequate attraction zones tourists would actually have interest visiting. Even though introduction of additional ferry lines cannot be considered as an effective solution for achieving optimal analyses results additional ferry capacities were implemented for some models. The main purpose of such an approach was to explore and identify system specifics as well as to help determine limitations of optimization approach and implementation of FQMS.

Modelling of road traffic flows requires extensive quantity of data and other related information about road network and travel demand. Additionally, the accuracy of modelled traffic situation depends on the quality of available information and how the data is combined and weighted according to different sources [4]. Therefore, two main problems appeared in the process of model creation: the first one being nonexistence of prior scientific research on a large modelling scale and the second one, limited sources of available statistical data. Regarding the mentioned context of model creation the main problem is complete nonexistence of OriginDestination (O-D) matrix describing road traffic network trip and load distribution. Therefore, the main challenge was to identify appropriate methodology that could be used for describing road traffic network load distribution in the analysed system. After reviewing various scientific models proposed for defining $\mathrm{O}-\mathrm{D}$ matrices and routes $[11 \div 13]$ using various approaches and methodologies no valid model was found which could be applied to specific phenomenon analysed in this paper. Studied methodologies can generally be divided into two major categories. Majority of them are mathematical models [4, $11 \div 13$ ] often presented lacking or with insufficient empirical analysis or inadequate and data intensive microscopic (i.e. Synchro SimTraffic) and macroscopic (i.e. Dynasim Cube) traffic oriented simulation tools with very specific applications mostly designed for urban areas.

Therefore, authors decided to use a general-purpose simulation tool suitable for system modelling on macroscopic scale and simultaneously allowing description of specific microscopic scale model attributes. Regarding their macroscopic scale, presented models can be described as time-independent (static) models but since microscopic elements like model entry distribution and link travel times have been implemented, the model could be best described as mesoscopic or hybrid.

The described modelling approach was supported and based on somewhat modified traditional traffic planning process developed during the 1950s and 1960s [5] consisting of four sequential stages-trip generation (total travel demand from each centroid), trip distribution (total O-D matrix), modal split (O-D matrix per travel mode; due to high percentage of personal vehicles in total road traffic this step was not implemented and all traffic was assigned as personal vehicle traffic) and traffic assignment (route-link flows). With the use of described methodology, it became possible to define road traffic network load and distribution based on a somewhat reduced input data set.

\section{Simulation model development \\ 3.1 Defining structure, input and output parameters of the analysed system}

The first step towards creating a computer model of the analysed system was to determine its structural elements. As such, road border crossings, road network, national parks and ferry ports, type, capacity and frequency of ferries were identified. Data regarding the number of tourists, border-crossing traffic, road traffic volume, national park visitors and number of vehicles transported on board ferries analysed in this paper refer to the period from 2006 until 2010. Special focus was given to identifying maximum vehicle entries for road border crossings (peak) during the main tourist season (summer period). With such criterion being set, all weekends including Fridays and Mondays between 1st of June and 1 st of September (depending on the year) were analysed. Results indicated that the weekend from $28^{\text {th }}$ July to $31^{\text {st }}$ July 2006 was the one with the highest number of vehicles registered and therefore used for input values in all models. Graphical representation of road traffic volume on Croatian road traffic network is presented in Fig. 1, and accompanied by locations of Croatian national parks, analysed border crossings, ports and ferry lines shown in Fig. 2.

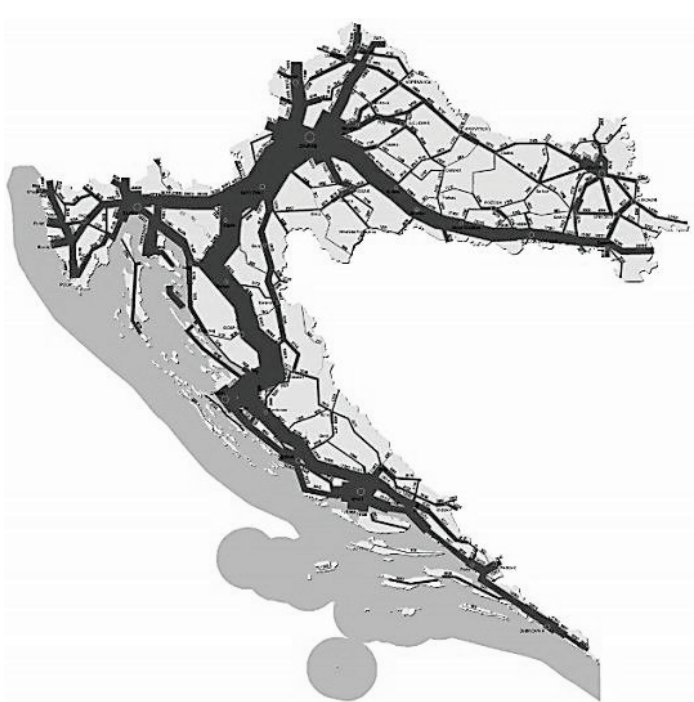

Figure 1 Road traffic volume on Croatian road traffic network (thicker line representing higher traffic volume; average summer daily volume for period 2006-10) [21]

Nowadays the southern part of the Croatian territory is marginalized in terms of transport, as one has to cross the border between the Republic of Croatia and Bosnia and Hercegovina in order to reach the southern part of Dubrovnik-Neretva County by means of road traffic. Due to geographic particularities of border crossing Klek - 
Zaton Doli and the fact that passengers and vehicles passing do not create additional demand on ferry transport this border crossing has not been included in the model. Based upon the analysis of available statistical data from the Croatian Bureau of Statistics (CBS) [3] seven referential road border crossings were identified as the most important: Plovanija, Pasjak, Rupa, Bregana, Macelj, Mursko Središće and Goričan.

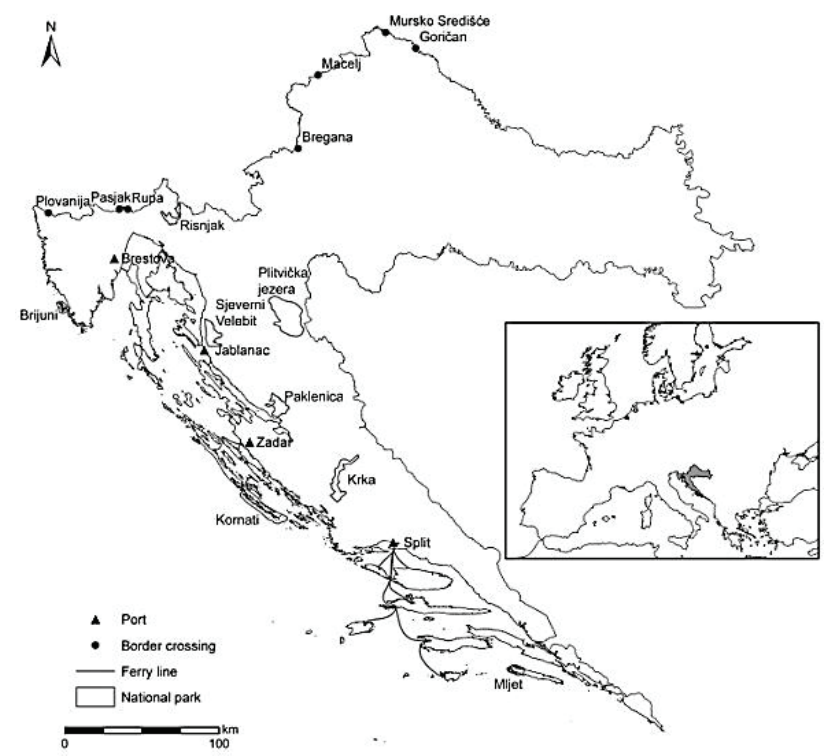

Figure 2 Locations of Croatian national parks, analysed border crossings, ports and ferry lines

The Ministry of Internal Affairs (MUP) provided the statistical data on the number of vehicles and passengers during the summer period. Based upon the acquired data it was possible to determine peak hours of inbound road network load that furthermore led to the defining of demand volume of ferry infrastructure. In terms of modelling process, the named road border crossings represent entity's (vehicles) entry points in the model whilst data about their peak load represent model's input parameters.

Additionally, data on road network load were acquired based on data available from the Croatian authorities responsible for road network maintenance; Croatian roads Ltd. (HC) and Croatian Motorways Ltd. (HAC) [21]. Road network attributes including link lengths between nodes and travel times were obtained using geographical information system of Croatian road network infrastructure [22].

Road traffic flow harmonization was introduced into the model by inclusion of Croatian national parks especially the ones located near major road networks. Seven National parks were identified and represented in the simulation model structure: Brijuni, Risnjak, Sjeverni Velebit, Plitvička jezera, Paklenica and Krka. The number of visitors needed for load description was derived based on available data on the annual number of visitors and average number of passengers per vehicle during peak load period [3].

Using the same principle based on the traffic volume, ferry ports and ferry lines were identified as the last model element. The selection process was based on statistical data provided by the Croatian Agency for
Coastal Line Maritime Transportation (AOLPP), Croatian national shipping company Jadrolinija and Rapska plovidba shipping company [23]. During the selection process, the primary criterion was the existence of ferry lines. Therefore, all ports and lines on which ferries do not operate were excluded from further analysis. According to available statistical data and requirements Brestova, Valbiska, Jablanac, Prizna, Zadar, Biograd na Moru, Split and Orebić ferry ports were identified as representative.

Among selected ferry ports, only Split and Zadar serve more than one ferry line. Due to the traffic volume in the Split and Zadar ports, five most important lines were chosen in Split and three in Zadar. For each ferry line, the summer season timetable defined by Jadrolinija and Rapska plovidba (ferry line Jablanac - Mišjak) was provided. Additionally, ferry capacity was also taken as an input parameter for calculation of each line's capacity. The output parameter calculated based on system elements was defined as waiting time needed for vehicle to be boarded onto ferry-que waiting line.

In conclusion, model entry points (road border crossings), harmonization points (national parks) and destination points (ferry ports) needed to be linked together and all links were assigned appropriate attributes such as distance, travel time for each link-route on analysed road network and road traffic volume. More precisely, it was necessary to determine the O-D matrix.

\subsection{Relations between analysed system elements regarding expected simulation output results}

Load volume of model elements and links was done based on peak period during the main tourist season. Analysis based on available statistical data clearly indicated the existence of peak days starting from Friday afternoon until Monday morning. Even in this initial model, the preparation phase, such a long peak period implied certain limitations of the FQMS system implementation that should not be perceived as sole model deficiency, but rather as the result of long and stable peak periods. It was quite challenging to get simulation results in terms of long lasting stable peak periods and limited road and ferry capacities without changing any of those inputs.

Another important fact, which needed to be properly addressed in terms of expected simulation results, is the fact that all vehicles designated to use ferry transportation service share the existing road network with all other vehicles travelling through the road network model. Therefore, they could not be analysed separately until they reach their destination ferry port.

\subsection{Selection of an appropriate simulation tool}

Regarding availability of various purpose simulation tools, it was necessary to determine a particular one that would enable to create a model of the analysed system along with all of its specifics. Three groups of simulation tools were included into reviewing process, tools specialized for simulating road traffic models (SimTraffic, Dynasim, VISSIM), mathematical simulation tools (Mathlab) and general scale simulation 
tools (Arena, Simul8). Taking into consideration specifics that would enable modelling of the FQMS system along with adequate but not too complex way of describing entities (vehicles) movement through nodes and links, simulation tool specifics and specialization, Simul8 simulation tool was finally chosen as optimal solution. Its features allowed modelling of traffic elements of the system on a macroscopic level whilst simultaneously allowing the defining of all relationship links in the analysed system that represented basic prerequisites for successful modelling of analysed phenomena.

One of the most important features of Simul8 tool is its ability to preload the analysed model before actual data acquisition starts enabling increased statistical exactness of gathered output data since no data was gathered before simulation model actually achieved its peak load.

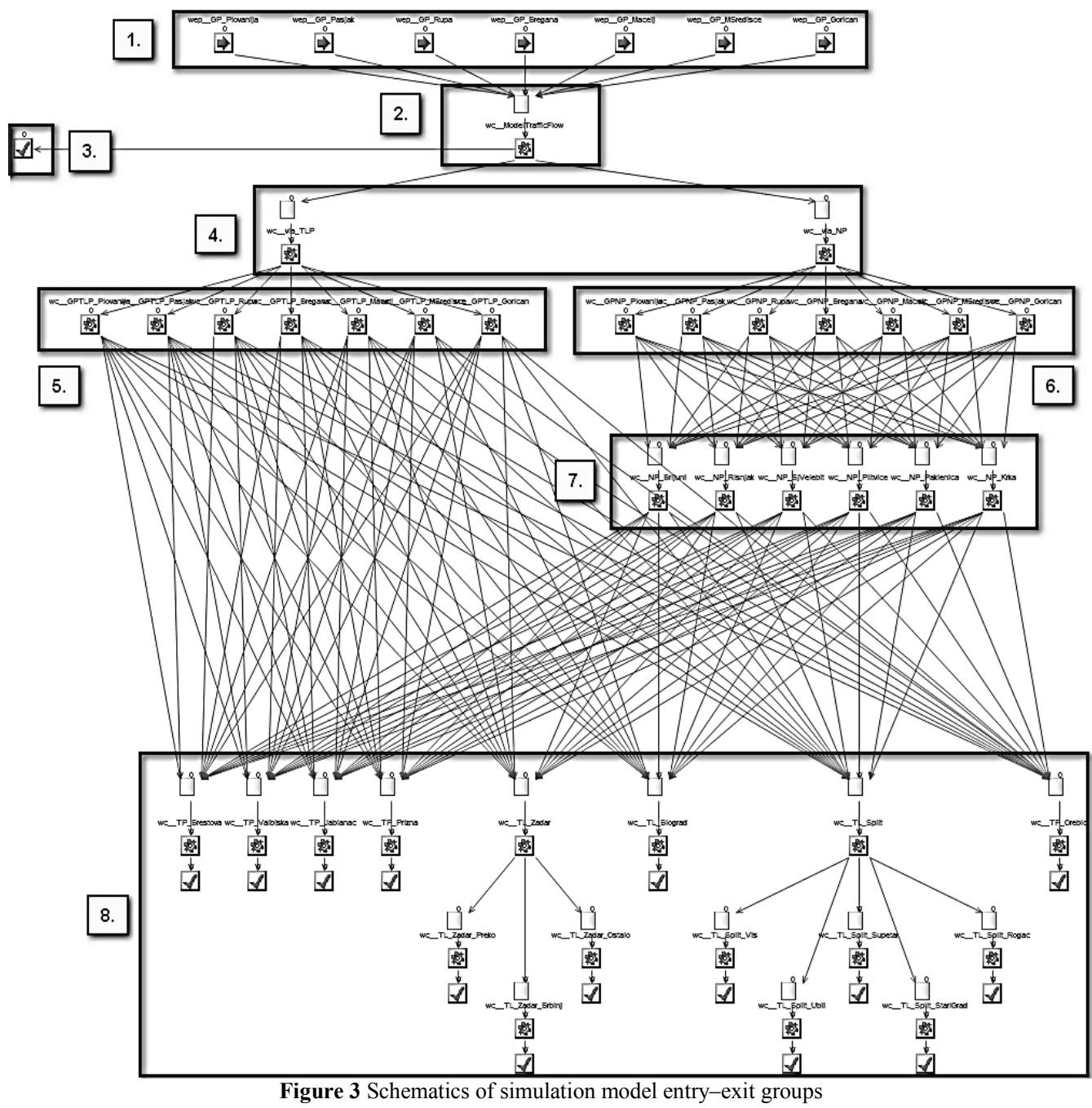

\subsection{Defining simulation model input-output structure, elements and their attributes}

Once all model elements and links were defined, the next step in the modelling process included grouping according to function in the model or simply defining model logic. As shown in Fig. 3, the model consists of eight entry-exit groups:

1) road border crossing vehicle entrance distribution group,

2) general vehicle distribution group (necessary to simulate the unavailable $\mathrm{O}-\mathrm{D}$ matrix),

3) exit distribution group (used to simulate vehicles which do not use ferry transportation services),

4) vehicle distribution group to simulate road network harmonization effect (vehicles tending to visit national parks),
5) vehicle distribution group for simulating standard road network load (vehicles which do not visit national parks),

6) distribution group used to simulate vehicle distribution towards different harmonization points (national parks),

7) distribution group describing harmonization points (national parks) capacities and

8) boarding elements representing ferry infrastructure.

The first step towards modelling entry attributes was defining of entity arrival distribution for all elements in the first model group. Arrival distribution was derived according to values shown in Tab. 1. Such arrival definition approach differs from the common arrival distribution used in road traffic models i.e., the number of vehicles in minutes, hours or day. According to its core features, the road traffic system represents discrete system, but when its load is constantly in the highest state 
of arrival rate it can be described/modelled using entities (vehicle) interarrival time.

The second entry-exit group consists of one element whose exclusive function is the same as that of two elements from the fourth group; elements used for entities distribution. Although their existence might seem somewhat unusual, it was conditioned by unavailability of the O-D matrix of the actual road traffic system. Therefore, the third group was modelled to simulate distribution of model entities that do and do not use ferry transportation services. The fifth and sixth entry-exit groups had a similar function as the second and fourth group essential for their implementation and arose as a consequence of unavailability of the O-D matrix. Accordingly, the named groups were used to create entities distribution within the simulation model as shown in Tab. 1. The seventh entry-exit group was used to additionally define entities movement towards model harmonization points. The eighth entry-exit group represents ferry infrastructure including ferry ports and ferries (their capacities and timetables) as shown in Tab. 2.

Table 1 Model entities interarrival time

\begin{tabular}{|c|c|c|c|c|c|c|c|}
\hline \multirow{2}{*}{$\begin{array}{l}\text { Road border } \\
\text { crossing }\end{array}$} & \multicolumn{3}{|c|}{ Number of vehicles } & \multirow{2}{*}{$\begin{array}{l}\text { Arrival interval } \\
\qquad(1 \mathrm{~min})\end{array}$} & \multirow{2}{*}{$\begin{array}{c}\text { Vehicles } \\
\text { using ferries } \\
(\%)\end{array}$} & \multirow{2}{*}{$\begin{array}{c}\text { Road } \\
\text { vehicles }(\%)\end{array}$} & \multirow{2}{*}{$\begin{array}{c}\text { Standardized } \\
(\%)\end{array}$} \\
\hline & in $24 \mathrm{~h}$ & in $1 \mathrm{~h}$ & in $1 \mathrm{~min}$ & & & & \\
\hline Macelj & 17116 & 713 & 11.89 & 0.0841 & \multirow{7}{*}{5.27} & 1.5964 & 26.58 \\
\hline Rupa & 8644 & 360 & 6.00 & 0.1666 & & 3.1611 & 13.42 \\
\hline Bregana & 20479 & 853 & 14.22 & 0.0703 & & 1.3343 & 31.80 \\
\hline Plovanija & 6275 & 261 & 4.36 & 0.2295 & & 4.3545 & 9.74 \\
\hline Pasjak & 8500 & 354 & 5.90 & 0.1694 & & 3.2146 & 13.20 \\
\hline Goričan & 1707 & 71 & 1.19 & 0.8436 & & 16.0073 & 2.65 \\
\hline M. Središće & 1683 & 70 & 1.17 & 0.8556 & & 16.2356 & 2.61 \\
\hline Total & 64404 & 2683.50 & 44.73 & & & & 100 \\
\hline
\end{tabular}

Table 2 Ferry capacities and frequency (timetable)

\begin{tabular}{|c|c|c|c|c|c|c|c|}
\hline \multicolumn{8}{|c|}{ Ferry } \\
\hline Line & Capacity & Freq. & Capacity/Day & Line & Capacity & Freq. & Capacity/Day \\
\hline Brestova-Porozina & 197 & 11 & 2167 & Biograd-Tkon & 36 & 13 & 468 \\
\hline Valbiska-Merag & 170 & 12 & 2040 & Split-Vis & 120 & 3 & 360 \\
\hline Jablanac-Merag & 63 & 23 & 1449 & Split-Ubli & 170 & 3 & 510 \\
\hline Prizna-Žigljen & 100 & 16 & 1600 & Split-Supetar & 138 & 14 & 1932 \\
\hline Zadar-Preko & 138 & 18 & 2484 & Split-Stari Grad & 130 & 7 & 910 \\
\hline Zadar-Brbinj & 100 & 4 & 400 & Split-Rogač & 60 & 6 & 360 \\
\hline Zadar-Other & 48 & 2 & 96 & Orebić-Dominče & 100 & 18 & 1800 \\
\hline
\end{tabular}

\subsection{Model structure and simulation methodology}

The modelling process in Simul8 consisted of three phases. The first phase included modelling of all defined system elements. The second phase included creating relationships-links between elements from the first phase in order to create a complete model infrastructure. Finally, the third phase included modelling road network entities behaviour in the model, including arrival distribution, travel distance and time, route selection and definition of ferry infrastructure capacities and frequencies. Vehicles' paths/routes have been determined as fixed distribution based upon level of available statistical and traffic data. The structure of a base model created in Simul8 is shown in Fig. 3. Additionally, Fig. 4 and Fig. 5 represent modified elements of base model structure shown in Fig. 3 that were used for analysis of the FQMS system implementation. All models consist of five different simulation object types as shown in Tab. 3 .

Table 3 Simulation objects used in the modelling process

\begin{tabular}{|c|c|c|}
\hline Type of Element & Model Nomenclature & Function Description \\
\hline Work Entry Point & wep_c_element_Name $>$ & Model entry points; used to (pre)load entities in model \\
\hline $\begin{array}{l}\text { Work Center } \\
\text { Queue }\end{array}$ & q_wc_<Element_Name> & $\begin{array}{l}\text { Tracking the number of entities and waiting times in queues; related to Work Complete } \\
\text { object }\end{array}$ \\
\hline Work Center & wc $<$ Element Name $>$ & Performing of entities work process in model \\
\hline Work Complete & Not used & Tracking of number of executed work processes; related to Work Complete objects \\
\hline Link & Not used & Used to describe links between model elements \\
\hline
\end{tabular}

Model analysis was performed upon a base model used to describe current state of the observed system. Other models had at least one modification introduced, but without changing the actual system input load with total count of 26 different models being analysed. Main model modifications consisted of the implementation of FQMS with variable user acceptance rate; number of vehicles appearing in the model using ferry transportation services which decided to take advantage of using this system and different variations of allocated ferry lines used for priority boarding purposes as well as adding new ferry capacities. The FQMS system load was tested at minimum load of $1 \%$ and followed by $5 \%, 10 \%, 20 \%$, and maximum load of $30 \%$ of all vehicles using ferry transportation services. Models were assigned into 6 groups with modifications implemented as shown in Tab. 4. 
Maximum FQMS load of $30 \%$ was adopted regarding polling results [3] while other values of $1 \%, 5$ $\%, 10 \%$ and $20 \%$ were set in order to provide better insight into the system behaviour under increased load. System load over $30 \%$ was not analysed as harmonization points would not endure a great load and overall system efficiency could therefore be greatly degraded. In addition, simulation results underlined this fact.

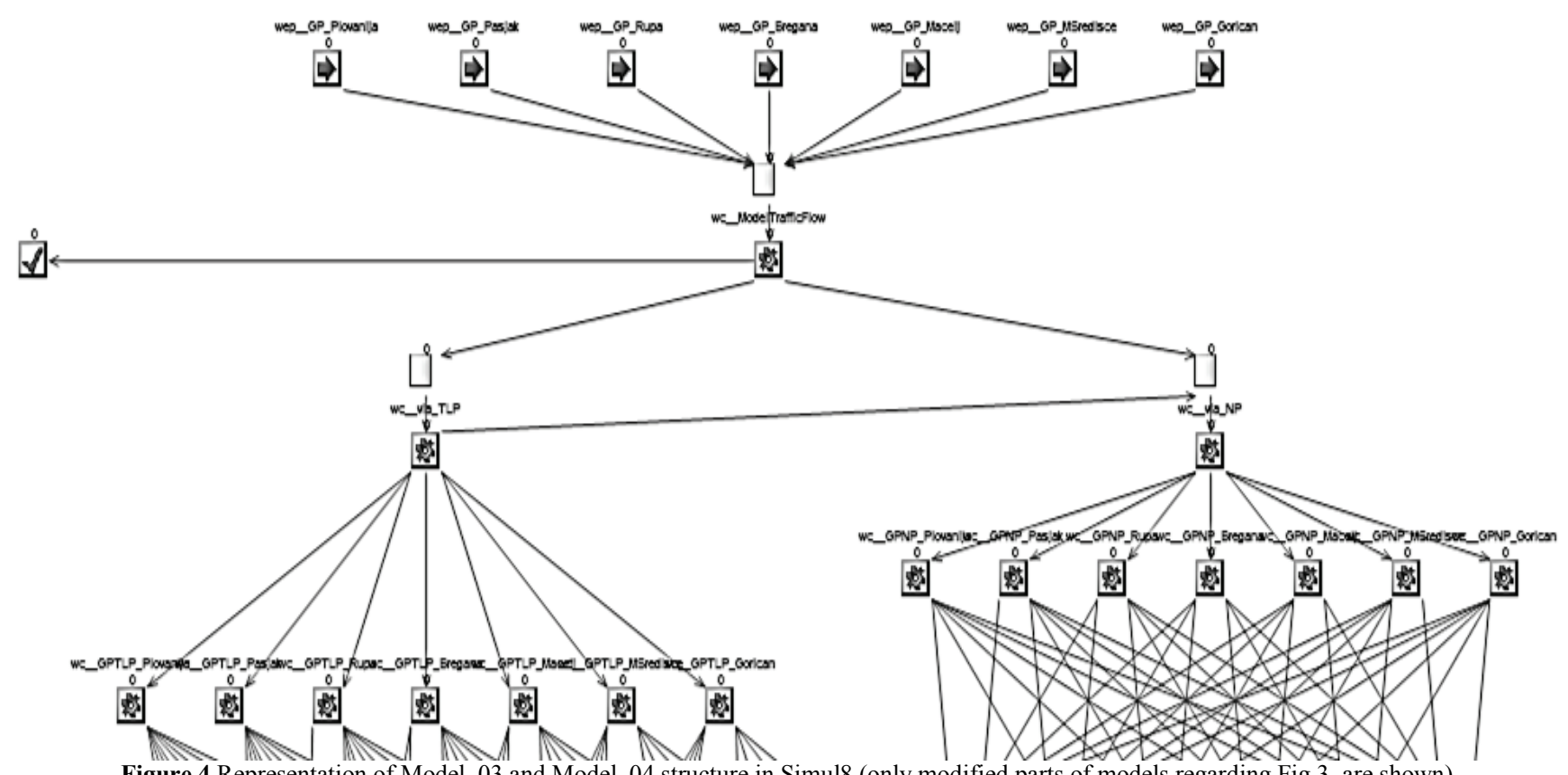

Figure 4 Representation of Model 03 and Model 04 structure in Simul8 (only modified parts of models regarding Fig 3. are shown)
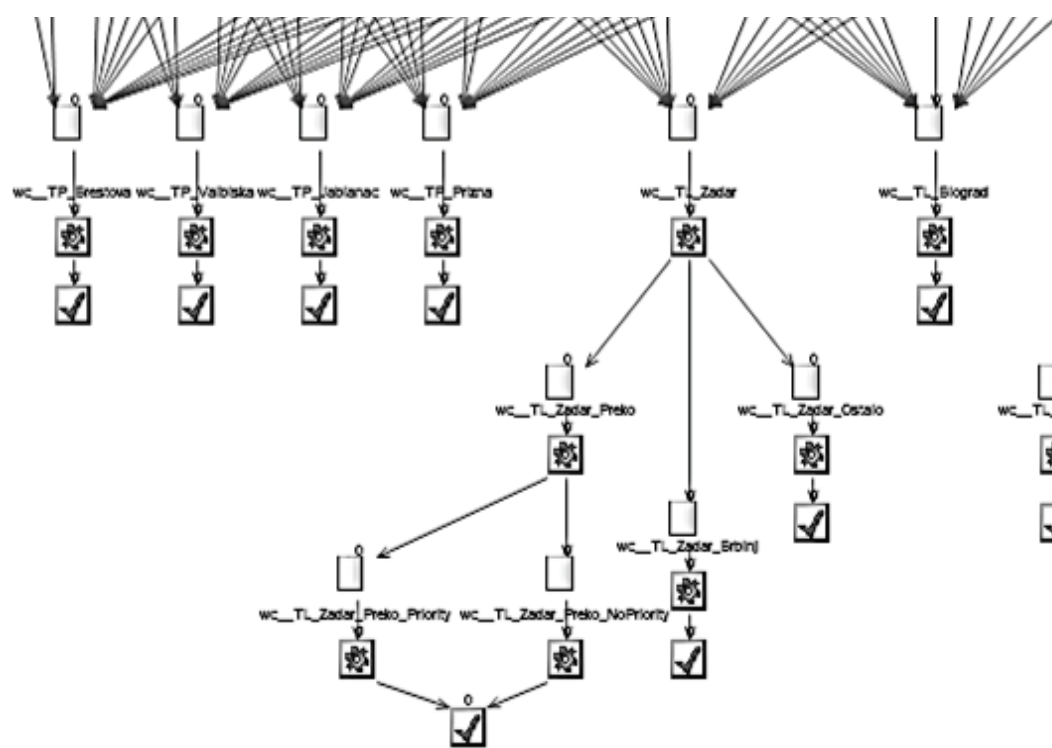

Figure 5 Representation of Model_05 and Model_06 structure in Simul8 (only modified parts of models regarding Fig. 3. are shown)

Table 4 Simulation of model groups characteristics and modifications

\begin{tabular}{|c|c|c|c|c|c|}
\hline \multirow{3}{*}{$\begin{array}{c}\text { Model } \\
\text { Group Name }\end{array}$} & \multicolumn{2}{|r|}{ FQMS } & \multicolumn{3}{|c|}{ Ferry Line Modifications } \\
\hline & \multirow{2}{*}{ Implemented } & \multirow{2}{*}{ Load Rate } & \multirow{2}{*}{ Time Table } & \multicolumn{2}{|c|}{ Additional Capacity } \\
\hline & & & & Priority boarding & Regular \\
\hline Model 01 & No & - & No & \multicolumn{2}{|c|}{ No; Together } \\
\hline Model 02 & Yes & Fixed; $10 \%$ & No & \multicolumn{2}{|c|}{ No; Together } \\
\hline Model 03 & Yes & Variable rate $; 1 \%, 5 \%, 10 \%, 20 \%, 30 \%$ & No & \multicolumn{2}{|c|}{ No; Together } \\
\hline Model 04 & Yes & Variable rate; $1 \%, 5 \%, 10 \%, 20 \%, 30 \%$ & Yes & \multicolumn{2}{|c|}{ Yes; Together } \\
\hline Model 05 & Yes & Variable rate; $1 \%, 5 \%, 10 \%, 20 \%, 30 \%$ & Yes & Yes & No \\
\hline Modle_06 & Yes & Variable rate; $1 \%, 5 \%, 10 \%, 20 \%, 30 \%$ & Yes & Yes & Yes \\
\hline
\end{tabular}

Models within groups Model_05 and Model_06 differed from other models regarding ferry ports distribution logic as they introduced a somewhat different optimization approach that included assignment of dedicated ferry lines for vehicles using the FQMS system and assigned with priority boarding privilege. Models within groups Model_01 through Model_05 also included priority boarding privilege but unlike models from 
Model_05 and Model_06 groups, vehicles assigned with priority boarding privilege had to be loaded aboard the same ferry as users that were not using FQMS. Unquestionably, certain limitations within such dedicated ferry line assignment approach had to be set. Therefore, vehicles with priority boarding privileges were limited/allowed exclusively to two dedicated ferry lines per day. When designated ferry lines were filled, another limitation was also set; users assigned for priority boarding could not be loaded aboard regular ferry lines.

As it has been previously mentioned, the increase of the number of ferries was also analysed but regarding ferry line specifics it was applied only to one ferry line; Zadar-Preko. Such scenario could have been applied on other ferry lines as well but bearing in mind the main idea presented in this paper together with the possibilities for analysis of optimizing the system within the boundaries of the existing ferry capacities it has not been implemented in other models.

\section{Simulation output analysis}

Summary results acquired upon conducted series of simulation runs of described models are presented in Tab.5. For easier results overview and comparison, results referring to models that included implementation of the FQMS are presented in the form of an average value. Afterward such average values were compared on model basis (columns named M_03, M_04, M_05 and M_06) and then compared to values of existing system state represented by model Model_01 (columns named M_01). All displayed values shown in Tab. 5 refer to the percentage change of analysed parameters. Values shown in other columns refer to values in minutes. All negative values represent reduction in waiting time and are to be referred to as desirable whilst all positive values can be referred to as undesirable. Based on presented values, FQMS implementation was analysed and conclusions were made regarding each ferry line served.

As expected, simulation results presented in Tab.5 clearly indicated output values are highly dependent upon several factors like the number of vehicles, number of ferries serving particular line and finally the ferry timetable (operation frequency). Certain models produced positive results of FQMS implementation for priority boarding vehicles whilst, at the same time, produced negative results for vehicles in regular waiting queue. Such outcome definitely justifies implementation of FQMS.

Comparison of presented simulation results in groups Model_01 and Model_02 clearly indicates how implementation of priority boarding in current state of the system was unable to produce a positive effect in some ferry ports and in some cases, even extremely undesirable results were achieved. In such cases, waiting time for priority boarding vehicles was extremely extended whilst, at the same time, reduction in waiting times for vehicles in regular waiting queue was achieved indicating implementation of priority boarding to be completely irrational. Even though such results could be unexpected taking into consideration the current state of the system under full load with constant vehicle arrival rate and given ferry capacities and their timetables, such an outcome was not unexpected. Nevertheless, such outcome only verifies the validity of created simulation models and the simulation tool itself regarding the general rule of conformity stating it is impossible to achieve further system optimization, if the system is already operating at its maximum capacity, without adding new service infrastructure elements into the model.

Table 5 Summary of all simulation runs results (presented values refer to time in minutes)

\begin{tabular}{|c|c|c|c|c|c|c|c|c|c|c|c|c|c|c|c|c|}
\hline & & Model_01 & Mod & del_02 & Model_03 & Cha & ange & Model_04 & Cha & inge & Model_05 & Cha & ange & Model_06 & Cha & inge \\
\hline QUE NAME & Priority & & $10 \%$ & M_01 & AVG & M_03 & M_01 & AVG & M_04 & M_01 & AVG & M 05 & M 01 & AVG & M_06 & M_01 \\
\hline \multirow{2}{*}{ q_wc_TP_Brestova } & No & 150 & 151 & $1 \%$ & 151 & & $1 \%$ & 151 & & $1 \%$ & 151 & & $1 \%$ & 151 & & $1 \%$ \\
\hline & Yes & & 143 & $-4 \%$ & 145 & $-4 \%$ & $-3 \%$ & 145 & $-4 \%$ & $-3 \%$ & 144 & $-4 \%$ & $-3 \%$ & 144 & $-4 \%$ & $-3 \%$ \\
\hline \multirow{2}{*}{ q_wc_TP_Valbiska } & No & 81 & 82 & $1 \%$ & 82 & & $1 \%$ & 82 & & $1 \%$ & 82 & & $1 \%$ & 82 & & $1 \%$ \\
\hline & Yes & & 80 & $-2 \%$ & 81 & $-1 \%$ & $-1 \%$ & 81 & $-1 \%$ & $-1 \%$ & 81 & $-2 \%$ & $-1 \%$ & 81 & $-2 \%$ & $-1 \%$ \\
\hline \multirow{2}{*}{ q_wc_TP_Jablanac } & No & 59 & 60 & $1 \%$ & 60 & & $1 \%$ & 60 & & $1 \%$ & 60 & & $1 \%$ & 60 & & $1 \%$ \\
\hline & Yes & & 50 & $-16 \%$ & 50 & $-17 \%$ & $-16 \%$ & 50 & $-17 \%$ & $-16 \%$ & 50 & $-17 \%$ & $-16 \%$ & 50 & $-17 \%$ & $-16 \%$ \\
\hline \multirow{2}{*}{ q_wc_TP_Prizna } & No & 79 & 79 & $1 \%$ & 80 & & $1 \%$ & 80 & & $1 \%$ & 80 & & $1 \%$ & 80 & & $1 \%$ \\
\hline & Yes & & 73 & $-7 \%$ & 73 & $-8 \%$ & $-7 \%$ & 73 & $-8 \%$ & $-7 \%$ & 73 & $-8 \%$ & $-7 \%$ & 73 & $-8 \%$ & $-7 \%$ \\
\hline \multirow{2}{*}{ q_wc_TL_Zadar_Preko } & No & 65 & 65 & $0 \%$ & 66 & & $1 \%$ & 41 & & $-37 \%$ & 83 & & $27 \%$ & 66 & & $1 \%$ \\
\hline & Yes & & 65 & $0 \%$ & 66 & $0 \%$ & $1 \%$ & 41 & $0 \%$ & $-37 \%$ & 409 & $393 \%$ & $527 \%$ & 409 & $523 \%$ & $527 \%$ \\
\hline \multirow{2}{*}{ q_wc_TL_Zadar_Brbinj } & No & 242 & 240 & $-1 \%$ & 240 & & $-1 \%$ & 240 & & $-1 \%$ & 240 & & $-1 \%$ & 240 & & $-1 \%$ \\
\hline & Yes & & 249 & $3 \%$ & 241 & $0 \%$ & $-1 \%$ & 241 & $0 \%$ & $-1 \%$ & 241 & $0 \%$ & $-1 \%$ & 241 & $0 \%$ & $-1 \%$ \\
\hline \multirow{2}{*}{ q_wc_TL_Zadar_Other } & No & 744 & 745 & $0 \%$ & 734 & & $-1 \%$ & 734 & & $-1 \%$ & 362 & & $-51 \%$ & 362 & & $-51 \%$ \\
\hline & Yes & & 745 & $0 \%$ & 715 & $-3 \%$ & $-4 \%$ & 715 & $-3 \%$ & $-4 \%$ & 365 & $1 \%$ & $-51 \%$ & 365 & $1 \%$ & $-51 \%$ \\
\hline \multirow{2}{*}{ q_wc_TL_Biograd } & No & 115 & 733 & $538 \%$ & 116 & & $1 \%$ & 116 & & $1 \%$ & 116 & & $1 \%$ & 116 & & $1 \%$ \\
\hline & Yes & & 114 & $-1 \%$ & 102 & $-12 \%$ & $-11 \%$ & 102 & $-12 \%$ & $-11 \%$ & 103 & $-11 \%$ & $-11 \%$ & 103 & $-11 \%$ & $-11 \%$ \\
\hline \multirow{2}{*}{ q_wc_TL_Split_Vis } & No & 269 & 102 & $-62 \%$ & 269 & & $0 \%$ & 269 & & $0 \%$ & 269 & & $0 \%$ & 269 & & $0 \%$ \\
\hline & Yes & & 272 & $1 \%$ & 267 & $-1 \%$ & $-1 \%$ & 267 & $-1 \%$ & $-1 \%$ & 268 & $0 \%$ & $0 \%$ & 268 & $0 \%$ & $0 \%$ \\
\hline \multirow{2}{*}{ q_wc_TL_Split_Ubli } & No & 295 & 281 & $-5 \%$ & 292 & & $-1 \%$ & 292 & & $-1 \%$ & 292 & & $-1 \%$ & 292 & & $-1 \%$ \\
\hline & Yes & & 292 & $-1 \%$ & 296 & $1 \%$ & $0 \%$ & 296 & $1 \%$ & $0 \%$ & 296 & $2 \%$ & $1 \%$ & 296 & $2 \%$ & $1 \%$ \\
\hline \multirow{2}{*}{ q_wc_TL_Split_Supetar } & No & 80 & 282 & $253 \%$ & 80 & & $0 \%$ & 80 & & $0 \%$ & 80 & & $0 \%$ & 80 & & $0 \%$ \\
\hline & Yes & & 80 & $0 \%$ & 73 & $-9 \%$ & $-9 \%$ & 73 & $-9 \%$ & $-9 \%$ & 72 & $-10 \%$ & $-9 \%$ & 72 & $-10 \%$ & $-9 \%$ \\
\hline \multirow{2}{*}{ q_wc_TL_Split_StariGrad } & No & 108 & 73 & $-32 \%$ & 108 & & $-1 \%$ & 108 & & $-1 \%$ & 108 & & $-1 \%$ & 108 & & $-1 \%$ \\
\hline & Yes & & 108 & $0 \%$ & 108 & $0 \%$ & $-1 \%$ & 108 & $0 \%$ & $-1 \%$ & 108 & $0 \%$ & $0 \%$ & 108 & $0 \%$ & $0 \%$ \\
\hline \multirow{2}{*}{ q_wc_TL_Split_Rogac } & No & 175 & 107 & $-39 \%$ & 179 & & $2 \%$ & 179 & & $2 \%$ & 179 & & $2 \%$ & 179 & & $2 \%$ \\
\hline & Yes & & 179 & $3 \%$ & 170 & $-5 \%$ & $-3 \%$ & 170 & $-5 \%$ & $-3 \%$ & 169 & $-5 \%$ & $-3 \%$ & 169 & $-5 \%$ & $-3 \%$ \\
\hline \multirow{2}{*}{ q_wc_TP_Orebic } & No & 48 & 173 & $257 \%$ & 49 & & $1 \%$ & 49 & & $1 \%$ & 49 & & $1 \%$ & 49 & & $1 \%$ \\
\hline & Yes & & 48 & $0 \%$ & 48 & $-2 \%$ & $-1 \%$ & 48 & $-2 \%$ & $-1 \%$ & 48 & $-2 \%$ & $-1 \%$ & 48 & $-2 \%$ & $-1 \%$ \\
\hline
\end{tabular}


Results obtained from the simulation of model group Model 02 provide clarification on negative results for priority boarding vehicles on certain ferry lines-low frequency leading towards lower daily ferry transportation capacity on the following ferry lines: Split-Vis, SplitUbli, Split-Starigrad, Split-Rogač, Zadar-Brbinj and Zadar-Other. Waiting times on mentioned ferry lines with priority boarding implemented were greater than in current state of the system which clearly indicates a case when priority boarding principle could not produce adequate optimization level and should not be applied. The analysis of the remaining ferry lines from group Model_02 reveals very low or non-existent shortening of waiting times for priority boarding vehicles as compared to the current system state. Although the implementation of priority boarding provided mostly undesirable results in Model_02 group there was still a positive change in waiting time for priority boarding vehicles by $16 \%$ on the ferry line Jablanac-Merag and a slight increase in waiting time of $1 \%$ for regular boarding vehicles. Model_02 group also provided an extreme example of undesirable priority boarding principle implementation on ferry line Biograd-Tkon for regular boarding vehicles where extreme increase of $538 \%$ in waiting time occurred as direct consequence of low ferry capacity disregarding relatively high ferry line frequency, resulting in overall lower daily ferry transportation capacity.

Based upon the reviewed simulation resultsimplementation of exclusive priority boarding principle on current state of the system, there is a strong indicator of positive effect of its implementation but only on ferry lines with greater daily ferry transportation capacities.

Results acquired from simulating model group Model 03 indicated positive effects-reduced waiting time for priority boarding vehicles for most ferry lines, especially for ferry line Jablanac-Merag (17\%), PriznaŽigljen (8 \%), Biograd-Tkon (12\%), Split-Supetar (9\%) and Split-Rogač $(5 \%)$. Similar positive effects for priority boarding vehicles are visible in comparison between model groups Model_03 and Model_01 for following ferry lines Jablanac-Merag (16\%), PriznaŽigljen (7 \%), Biograd-Tkon (11\%) and Split-Supetar (9 $\%)$. Following ferry lines also produced positive effects of FQMS implementation: Brestova-Porozina (3\%), Valbiska-Merag (1\%), Zadar-Brbinj (1\%), Zadar-Ostalo (4\%), Biograd-Tkon (11\%), Split-Vis (1\%), SplitSupetar (9\%), Split-Stari Grad (1\%), Split-Rogač (3\%) and Orebić- Dominče (1\%). A negative effect for priority boarding vehicles was achieved only for ferry line ZadarPreko $(1 \%)$ along with a neutral effect for ferry line Split-Ubli $(0 \%)$ but at the same time FQMS implementation for this particular line caused regular vehicles waiting time of $1 \%$.

Simulation results from model group Model_04 regarding almost the same modes configuration as in model group Model_03 produced the same results except for ferry line Zadar-Preko. Extreme change reduction of waiting time for both priority and regular boarding vehicles of $37 \%$ achieved for this particular line clearly identified ferry capacity as one of the most important elements in que optimization process and clearly signalled the potential of increasing ferry capacities on overall FQMS optimization. Results acquired upon model group
Model 05 simulation produced extremely negative results for ferry line Zadar-Preko causing waiting time increase of $393 \%$.

By comparing model groups Model_05 and Model_01 for ferry line Zadar-Preko, extreme increase in waiting time of $527 \%$ for priority boarding vehicles has been achieved. Except the increase of waiting time for priority boarding vehicles, increase in the waiting time of $27 \%$ occurred for regular boarding vehicles as well. Such negative simulation outcome excluded the possibility of FQMS implementation on analysed ferry line. Moreover, it clearly indicated inadequacy of introducing separated ferry lines for priority and regular boarding vehicles.

Comparison of model groups Model 06 and Model 01 on ferry line Zadar-Preko, indicated extreme increase of waiting time $(527 \%)$ for priority boarding vehicles. Except for priority boarding vehicles, waiting time would also increase $(1 \%)$ for regular boarding vehicles. The acquired result definitely excludes the possibility of FQMS implementation in case separate ferries would be allocated exclusively for priority boarding vehicles.

If any analysis should be conducted based on proposed methodology one should take into consideration one final remark regarding interpretation of simulation output results presented in Tab. 5. For easier understanding, all comparisons in this paragraph were described in terms of percentage values. Although presented percentage values for some ferry lines are of higher value, their significance (pondered value) should always be analysed in the context of the exact number of vehicles being served and corresponding waiting time in minutes for each ferry line in order to produce a real image of FQMS implementation effect rather than just by percentage value.

\section{Conclusion}

The simulation output analysis clearly indicated FQMS implementation is feasible for most of the analysed ferry lines. Best optimization results were achieved on ferry lines with low capacity (between 50 and 100 vehicles) and high frequency (more than 20 turnarounds per day), i.e. ferry line Jablanac-Merag. Somewhat lower, but still significant optimization results were achieved on ferry lines with low capacity (less than 50 vehicles) and medium frequency (between 10 and 20 turnarounds per day), i.e. ferry line Biograd-Tkon as well as on ferry lines with medium capacity (between 100 and 150 vehicles) and medium frequency, i.e. ferry lines Split-Supetar and Prizna-Žigljen. Therefore, it can be concluded that FQMS implementation is feasible for ferry lines with both lower and higher number of vehicles on board. FQMS implementation also confirmed the optimization process can produce unilateral benefits; more specifically not only can it decrease waiting time for priority boarding vehicles, but it can lead to minimal increase of waiting times for regular boarding vehicles. According to results presented in Tab. 5, waiting time for regular boarding vehicles would remain the same for two ferry lines (Split-Vis and Split-Supetar); for ferry line Split-Rogač it would have a maximum increase of $2 \%$, and all other ferry lines would experience an increase of 
$1 \%$. In general, obtained results confirm feasibility of FQMS implementation.

Another aspect that was analysed by simulation models confirms FQMS consistency and ability to achieve improved results even with increased number of users. This is proven by very low deviation (increase) in waiting time for priority boarding vehicles when FQMS recorded increase in the number of users.

The simulation analysis confirmed that current ferry line allocation without separating priority and regular boarding vehicles (allocating special ferries just to board priority boarding vehicles) with simultaneous FQMS implementation does provide the best possible management solution.

FQMS implementation simulation nevertheless also pointed out some negative effects and confirmed introductory hypothesis saying it is impossible to optimize a system that is already operating at maximum capacity level without introducing new (ferry) capacities into the system. This can be seen on the example of Zadar-Preko ferry line that is the line with the highest number of transported vehicles. In this case, simulation results confirmed increase of waiting time for both priority and regular boarding vehicles of $1 \%$. This is the obvious proof of FQMS implementation limitations.

Since definition of exact FQMS implementation limits goes beyond the scope of this paper it remains to be additionally analysed in the future research. Additionally, further research is planned to be conducted regarding validation and verification of presented model(s) based on the next 5-year period (years 2011 to 2016) by adding the option of two-way direction analysis. In addition, conclusions presented in this paper do represent a quality background for conducting optimization of each ferry line separately and therefore determining their boundaries and optimal management model.

\section{References}

[1] Transportation Research Board. 75 Years of the Fundamental Diagram for Traffic Flow Theory, Washington DC, Transportation Research Board, 2011.

[2] May, A. D. Jr. Traffic Flow Fundamentals, Englewood Cliffs New Jersey, Prentice-Hall, 1990.

[3] Zupanovic, D. Advanced Ferry Ports Infrastructure Capacities Management System, Zagreb, Faculty of economics and business Zagreb, 2011.

[4] Peterson, A. The Origin-Destination Matrix Estimation Problem-Analysis and Computations, Norrköping, Linköping University, 2007.

[5] Papacostas, C. S.; Prevedouros, P. D. Transportation Engineering and Planning, 3rd edition, Upper Saddle River, New Jersey, Prentice Hall, 2001.

[6] Robertson, D. I. Research on the TRANSYT and SCOOT method of signal coordination. // ITE Journal. (1986), pp 36-40.

[7] Robertson, D. I.; Bretherton, R. D. Optimizing networks of traffic signals in real time-the SCOOT method. // IEEE Transactions on Vehicular Technology. 40, (1991), pp. 1115. https://doi.org/10.1109/25.69966

[8] Luk, J. Y. K.; Sims, A. G. Selecting Offsets for Sub-Area Linkage in SCATS. // Australian Road Research. 12, 2(1982), pp. 71-84.

[9] Dion, F; Hellinga, B. A rule-based real-time traffic responsive signal control system with transit priority:
Application to an isolated intersection. // Transportation Research Part B Methodological. 36, 4(2002), pp. 325-343. https://doi.org/10.1016/S0191-2615(01)00006-6

[10] Feng, S.; Wu, H.; Sun, X.; Li, Z. Factors of Perceived Waiting Time and Implications on Passengers' Satisfaction with Waiting Time. // Promet - Traffic \& Transportation. 28, 2(2016), pp. 155-163. https://doi.org/10.7307/ptt.v28i2.1726

[11] Bera, S.; Rao, K. V. K. Estimation of origin-destination matrix from traffic counts: the state of the art. // European Transport. 49, (2011), pp. 3-23.

[12] Lai, X.; Li, J.; Li, Z. A Subpath-based Logit Model to Capture the Correlation of Routes. // Promet - Traffic \& Transportation. 28, 3(2016), pp. 225-234. https://doi.org/10.7307/ptt.v28i3.1808

[13] Mrgole, A. L.; Sever, D.; Incorporation of Duffing Oscillator and Wigner-Ville Distribution in Traffic Flow Prediction. // Promet - Traffic \& Transportation. 29, 1(2017), pp. 13-22. https://doi.org/10.7307/ptt.v29i1.2116

[14] Sims, A. G. The Sydney coordinated adaptive traffic system. // Engineering Foundation Conference on Research Directions in Computer Control of Urban Traffic Systems, 1979, pp 12-27.

[15] Wongpiromsarn T.; Uthaicharoenpong, T.; Wang, Y.; Frazzoli, E.; Wang, D. Distributed Traffic Signal Control for Maximum Network Throughput. // $15^{\text {th }}$ International IEEE Conference on Intelligent Transportation Systems, 2012, pp. 588-595. https://doi.org/10.1109/ITSC.2012.6338817

[16] Sinha, R.; Roop, P.; Ranjitkar, P.; Zeng, J.; Zhu, X. Model-Based Design of Coordinated Traffic Controllers. // $20^{\text {th }}$ ITS World Congress, 2013, pp. 11.

[17] Hu, J.; Park, B. B.; Lee Y. J. Coordinated transit signal priority supporting transit progression under Connected Vehicle Technology. // Transportation Research Part C Emerging Technologies. 55, (2014), pp. 393-408. https://doi.org/10.1016/j.trc.2014.12.005

[18] Kim J. L.; Liu, J.-C. S.; Swarnam, P. I. The Areawide Real-Time Traffic Control (ARTC) System: A New Traffic Control Concept. // IEEE Transactions on Vehicular Technology. 42, 2(1993), pp. 212-224. https://doi.org/10.1109/25.211459

[19] Greenshields, B. D. A study of traffic capacity. // 14th Annual Meeting Highway Research Board, Wahington, 1935, pp. 448

[20] Chong-White, C.; Aydos, J. C.; Mehaffey, A. A demonstration of traffic control algorithm analysis in the field. 2015. http://www.transportationgroup.nz/Subgroups/ SNUG/Events/Workshops/2015/Day\%202/A\%20demonstr ation $\% 20$ of $\% 20$ traffic $\% 20$ control\%20algorithm\%20analysi s\%20in\%20the\%20field\%20ITSWC2015_Present_(v5Post Feedback).pptx. (12.12.2015)

[21] Hrvatske ceste d.o.o. Traffic counting on the roadways of Croatia. 2015. http://www.hrvatske-ceste.hr/default.aspx? id $=46(07.06 .2015)$

[22] Hrvatski auto klub d.o.o. Interactive Map. 2015. https://map.hak.hr (08.06.2015)

[23] Agencija za obalni linijski pomorski promet. 2015. http://www.agencija-zolpp.hr (04.03.2015) 


\section{Authors' addresses}

Dino Županović, PhD, Associate Professor University of Zadar, Maritime Department Mihovila Pavlinovića 1, HR-23000 Zadar, Croatia dino.zupanovic@unizd.hr

Ana Pejdo, PhD, Assistant Professor

University of Zadar, Department of Geography

Dr. Franje Tuđmana 24, HR-23000 Zadar, Croatia apejdo@unizd.hr

Lena Mirošević, PhD, Assistant Professor

University of Zadar, Department of Geography

Dr. Franje Tuđmana 24, HR-23000 Zadar, Croatia 1mirosev@unizd.hr 